\title{
25 Research Square \\ Marketing and Value Addition of Artemisia Annua Species and Other Potential Medicinal Plants in Southern Ethiopia
}

Gezehagn Gesese Gelgelo ( $\nabla$ gezugesemarry@gmail.com )

Wondo Genet College of Forestry and Natural Resources https://orcid.org/0000-0001-7427-9540

Solomon Erifo Nunie

Wondo Genet College of Forestry and Natural Resources

Tsegaye Bekele Mekonnen

Wondo Genet College of Forestry and Natural Resources

Kendisha Soekardjo Hintz

Technische Universität Dresden

\section{Research Article}

Keywords: Medicinal value, Traditional healers, Market margin, Value chain

Posted Date: December 15th, 2021

DOI: https://doi.org/10.21203/rs.3.rs-1147759/v1

License: (c) (1) This work is licensed under a Creative Commons Attribution 4.0 International License. Read Full License 


\section{Abstract}

Background: Medicinal plants play a pivotal role in the traditional medicine system in Ethiopia. Since the outbreak of the COVID-19 pandemic, domestic demand for medicinal plants has increased, particularly for Artemisia annua species. However, coupled with the secrecy nature in medicinal plant utilization, knowledge regarding marketing and value addition of medicinal plants is lacking in the literature. The objective of the present market study was to investigate the marketing and value addition of Artemisia annua and other major medicinal plants in selected towns of Southern Ethiopia.

Methodology: Primary data were collected using questionnaire, focus group discussions, and personal observations with producers and traders. Marketing benefits of the potential medicinal plants were captured by total return and marketing margins.

Result: The major medicinal plants in Chencha area were Artemisia annua, Stevia rebaudiana, and Silybum marianum, Echinops kebericho and Silene macrosolen Steud are widely used in Tula and Hawassa; Ocimum tenuiflorum and Ruta graveolens were found in Basha area, while Zehneria scabra was found in Chencha and Basha. The above-mentioned medicinal plants are used to treat various illnesses, while generating income to the local communities. The marketing or profit margins of the value-added products indicated a share of $28.6 \%, 14.36 \%$, $14.31 \%$, and $42.73 \%$ for producers, local collectors, and traders in Arbaminch and Addis Ababa, respectively.

Conclusion: Up scaling the cultivation and commercialization of these medicinal plants has the potential to maintain the public health while providing alternative income sources for local communities in Ethiopia. In an effort to capture local value addition of medicinal plants, processing materials, market outlets, and road infrastructures should be improved.

\section{Introduction}

In Ethiopia, medicinal plants are a fundament in the traditional healthcare system, play a major role in maintaining rural livelihoods as a non-timber forest product, and be an incentive to conserve forests (Tuasha et al. 2018; Guchale 2021; Agize and van der Zouwen 2016). It is estimated that $80 \%$ of the Ethiopian population depend on traditional medicines for the healthcare of not only humans, but also livestock animals (Tuasha et al 2018; Tegen et al. 2021). Due to the economic affordability, efficacy against certain diseases, and the trust communities have in the medicinal values of traditional medicines, medicinal plants are constantly in demand in Ethiopia (Bekele 2007; Tegen et al. 2021). Since the outbreak of the COVID-19 pandemic, there has been a race to find potential medicinal plants to treat the consequent respiratory disease, including in Ethiopia (Tegen et al. 2021). Among the 56 medicinal plants with antiviral properties identified by Tegen et al. (2021), Artemisia annua species was found as a candidate due to its artemisinin content. The market demand and price of Artemisia annua species in Ethiopia have increased since the start of the pandemic.

Despite the rise in ethnobotanical studies in Ethiopia in recent years, the ethnobotanical documentation of the major medicinal plants endemic to Ethiopia is still scanty (Bekele 2007; Yineger and Yewhalaw 2007; Tuasha et al. 2018). The knowledge on medicinal plants in Ethiopia is virtually oral and traditional medicinal knowledge is subject to secrecy (Tuasha et al. 2018; Guchale 2021). Medicinal plants and the related traditional medicinal knowledge are in gradual decline due to deforestation, environmental degradation, and acculturation (Giday et al. 2009). Furthermore, the value chain of medicinal plants among upstream actors, i.e. farmers, is associated to be informal in nature (Agize and van der Zouwen 2016). The utilization of traditional medicinal plants as non-timber forest products has 
to be strengthened with sustainable value addition and marketing approaches (Narita et al., 2018), so as to send positive market signals to farmers.

Therefore, this study aimed to investigate marketing and value addition of Artemisia annua species and other major medicinal plants in the selected towns of southern Ethiopia. To achieve this aim, the study specifically a) identified the marketing potential of medicinal plants and related value addition activities in the study areas, b) analysed the economic benefit of Artemisia annua in relation to other major medicinal plants, c) estimated the amount of value added at each stage of value addition activities of $A$. annua by the actors, and d) identified opportunities and challenges in marketing the studied medicinal plants.

\section{Methodology}

\section{Description of the study areas}

Owing to the agro-ecological zones, the greater concentration of medicinal plants is found in the south and southwestern Ethiopia (Edwards 2001 in Bekele 2007). In light of this, the market study was conducted in southern Ethiopia, particularly in Chencha district in Gamo zone, Southern Nations, Nationalities, and People's Region (SNNPR); and Tulla sub city and Hawassa city, Sidama Regional State, as shown in Figure 1 below. Chencha District is located $444 \mathrm{~km}$ form Addis Ababa in the Gamo zone of SNNPR State of Ethiopia (Seid and Aydagnehum, 2013). The district encompasses 54 Kebeles with 111,686 people (CSA, 2007) living in total area coverage of 37,650 ha $\left(373.6 \mathrm{~km}^{2}\right)$ and altitudes range from 1600-3200 m.a.s.I. Its agro-ecological climate ranges from Dega (2300-3200 m.a.s.l) to Woinadega (1500-2300 m.a.s.l). The mean annual temperature and rainfall are $22.50^{\circ} \mathrm{C}$ and $1201-1600$ $\mathrm{mm}$, respectively. The land use system of the area includes cultivated land (55.26\%), grazing land (8.51\%), forest and shrubs (15.47\%) and settlement and other purposes (20.76\%) (Seid and Aydagnehum, 2013). Hawassa city is located $273 \mathrm{~km}$ south of Addis Ababa at $7^{\circ} 3^{\prime} 1.35^{\prime \prime} \mathrm{N}$ and $38^{\circ} 29^{\prime} 43.81^{\prime \prime E}$ latitude and longitude, respectively. The total area coverage of the city is $50 \mathrm{~km}^{2}$. The population of the city is estimated to be 315,018 (CSA, 2007). It is located at the eastern shore of Lake Hawassa. The annual rainfall of the study area is about $950 \mathrm{~mm}$ and the mean temperature is $20^{\circ} \mathrm{C}$ (Scott et al., 2016). The city is administratively divided into 8 sub-city administrations with 32 Kebeles. Among the sub-cities, Tula sub-city is focused in this case study as a source of medicinal plant products that are marketed in Hawassa city (Scott et al., 2016).

\section{Sample Size and Sampling Techniques}

Multi-stage sampling procedures were employed to select specific Artemisia annua cultivators in the study areas. First, three study areas (Chencha District, Hawassa city, and Tula Sub-city) were chosen. Second, Artemisia annua cultivators were identified in all the selected study areas. Finally, using a snowball sampling technique, 70 respondents, including farmers (cultivars of Artimesia annua and other major traditional medicinal plants), traders and traditional healers were selected (Table 1). 
Table 1

Respondents distribution in the study areas

\begin{tabular}{|llll|}
\hline Area Descriptions & \multicolumn{2}{l|}{ Number of respondents $(\mathbf{n = 7 0 )}$} \\
\cline { 2 - 4 } & Farmers $(\mathbf{n = 5 0 )}$ & $\begin{array}{l}\text { Traditional healers } \\
(\mathbf{n}=\mathbf{8})\end{array}$ & $\begin{array}{l}\text { Traders } \\
(\mathbf{n}=12)\end{array}$ \\
\hline Chencha District & 32 & 5 & 3 \\
\hline Hawassa city & 8 & 1 & 6 \\
\hline Tula sub-city (Chafasine kebele) & 10 & 2 & 3 \\
\hline Source: Survey data result, 2021 & & & \\
\hline
\end{tabular}

\section{Interviews}

\section{Questionnaire Interview}

The interview was conducted with purposively selected traditional healers in the local society about the adoption of Artemisia annua and other medicinal plants widely used in the areas. The interview conducted with Artimesia annua cultivating farmers focused on the economic benefits of Artemisia annua. and other locally-known medicinal plants used by traditional healers in the study areas.

\section{Key Informant Interviews}

The key informant interview was primarily conducted with initial cultivators (50 respondent farmers) of Artemisia annua and other medicinal plants in Tula and Hawassa towns of Sidamo region, and Chencha, Gofa Zone. Key informant interviews were also carried out with eight traditional medicine healers who have first-hand information about the medicinal plants and their market values. Moreover, discussions were held with five individuals undertaking value addition activities of medicinal plants who also supplied the products to local and national markets.

\section{Market Survey}

A market survey was conducted by vising different local markets of Chencha district (Chencha town and Dorze markets), Tula sub city (Tula market), Basha (Basha and Kela markets), and Hawassa city (old and new markets) to identify the potential medicinal plants supplied to the markets and capture consumers' preferences, awareness about the medicinal plants in the market, and their price information. Moreover, data from traders and other major actors in Artimesia annua value chain were collected regarding treatment use recommendations and value addition activities. The information and data captured through the market survey were useful in triangulation.

\section{Focus Group Discussion}

Two focus group discussions involving eight persons were held with farmers cultivating and supplying medicinal plants to consumers. The group discussions focused on cultivation, management, market opportunities, market 
economic benefits, and constraints related to Artemisia annua and other medicinal plants in the study areas. The focus group discussions were vital and critical to strengthen the quality of information and complement the information overlooked by other methodological approaches. It was carried out at the three study areas consisting of Chencha, Chafasine, and Hawassa city and immediately after questionnaire and key informant interviews.

\section{Market and Economic Benefit Analysis Economic Performance}

Market performance analysis of medicinal plants in each study area was measured by variables like prices, costs, and volume of outputs of the producers per annum. In this study the following analysis were conducted to measure the market performances of the medicinal plants and compare their market value in the study areas.

\section{- Total return}

$R_{i}=P_{i} * Q_{i} \ldots \ldots \ldots i . i=1,2,3,4 \ldots \ldots$

Where:

R: is revenue obtained from selling medicinal plant products per year

P: Market price of medicinal plants per unit

Q: Quantity of medicinal plants harvested

i. different medicinal plant

\section{- Marketing Margin}

Here the marketing margin of the medicinal plant market actors were determined to know whether there is a fair share in relation to value added during the cultivation and marketing processes.

The marketing margin was determined using the following equation for value adding actors of the medicinal plant and potential traditional healers

$$
\text { Marketmargin }(\%)=\frac{\text { Sellingprice }- \text { purchaingprice }}{\text { consumerprice }} * 100
$$

Value added marketing channels of the medicinal plants were also identified and mapped.

\section{Market Conduct Analysis}

Market conduct analysis was also carried out to investigate the possible competitive or exploitative relationships between sellers and buyers of Artemisia annua and other medicinal plants (including traditional healers). The following were addressed during the market conduct analysis of this study

- Pricing strategy followed by the cultivators and buyers of medicinal plant cultivators

- Product strategy followed by medicinal plant product suppliers in each study area

- Responsiveness to change by the different medicinal plant healers in each study area compared to others 
- Advertising mechanisms employed by value adding actors of medicinal plant cultivators in each study area

\section{Limitation of the Study}

The limitation of this study comprises the lack of information available regarding traditional medicine plant products like quantity harvested and sold in the market. In the local society, the farmers, traditional healers, and traders were unwilling to provide information to keep the secrecy of traditional knowledge. Moreover, the absence of information recorded keeping culture in local society concerning the family and employed labor costs also affected the interpretation of the study results. The limitation also impacted to some extent the competence of appropriate and recommended dosage of traditional medicines made by the traditional healers and traders in the local markets. This constrained the scientific value addition and legitimacy aspects of traditional medicines. Thus, this circumstance comes across to realize efforts in understanding the value chain governance and market performance of these findings of the current traditional medicinal plants.

\section{Results And Discussions}

\section{Combination of Potential medicinal plants cultivated by farmers}

In the study areas, the farmers cultivate different traditional medicinal plants simultaneously and in combination for medicinal and marketing purposes. Studies on medicinal plants confirmed that intermixing multipurpose plants in home gardens and in farm fields pose numerous advantages to indigenous people (Agize et al. 2013; Yirga 2010). Out of the total sample of 50 farmers across the study areas, a total of nine major medicinal plants were identified (Table 2 or see sub-chapter 3.2).

Table 2

Combination of potential medicinal plants cultivated by farmer sample respondents

\begin{tabular}{|llc|}
\hline Traditional Medicinal plants & Respondents (n=50 farmers) \\
\cline { 2 - 3 } & Frequency & Percent \\
\hline $\begin{array}{l}\text { Artemisia annua, stevia (stevia rebaudiana Bertoni), milk thistle (Silybum } \\
\text { marianum) in Chencha }\end{array}$ & 12 & $24 \%$ \\
\hline Artemisia annua and stevia (stevia rebaudiana Bertoni) in Chencha & 17 & $34 \%$ \\
\hline Milk thistle (Silybum marianum) in Chencha & 3 & $20 \%$ \\
\hline $\begin{array}{l}\text { Artemisia annua, zehneria scabra (Beso Baqulla) and wogert (Silene } \\
\text { macroselen) in Chefasine }\end{array}$ & 10 & $16 \%$ \\
\hline Others in Chencha, Shashemene, Basha, Hawasssa & 8 & $20 \%$ \\
\hline Source: Survey data result, 2021 & & \\
\hline
\end{tabular}

The traditional medicinal use services are provided by traditional healers, farmers and traders in the study areas. About 8 traditional healers, 50 sample farmers and 12 traders (Hawassa, Chencha, Arbaminch, Basha and Tula) were used to have information regarding marketing and value addition elements (access to support, pricing mechanism, information access, and trust among actors) relevant to the traditional medicinal plants value chain governance (Table 3). 
A total of 43 (61.43\%) of the respondents have access to support from secondary value chain actors in the form of financial support from PhytoWood project for farmers in Chefasine Kebele, Tula sub-city, and extension and training support from Kalehiwot Church for farmers in Chencha. Meanwhile, 37 (38.57\%) of the respondents mentioned that they do not get any support both from governmental or non-governmental organizations. This suggests the need to upscale support provided by secondary value chain actors. Such support can assist smallholder farmers to bear the costs of accessing information, organising themselves and capturing the existing and potential traditional medicinal plant products market opportunity (Cunningham et al., 2008; Porter, 1985).

In addition, the respondents follow different price-setting mechanisms to market their traditional medicinal plant's value-added product. All of the farmers interviewed $(n=50)$ followed negotiable price setting mechanism. Meanwhile, the traders and traditional healers $(n=20)$ followed fixed price setting mechanism, as also confirmed during the focus group discussions. It was observed that actors used horizontal or vertical linkages while marketing traditional medicinal products based on the fundamental concept of trust (Kaplinsky and Morris, 2000; Piters et al., 2006). Similarly, 39 (55.71\%) of the respondents have trust to each other (especially, those in Chencha), of which 30 were farmers and nine traders. Meanwhile, the remaining 31 (44.29\%) respondents had no trust to each other. None of the traditional healers had trust to each other. The absence of trust between actors, especially among traditional healers, is due to the cultural values of the society and the secrecy nature in practicing traditional medicine (Agize et al., 2013; Hunde and Asfaw, 2006; Kindie and Tamiru, 2021; Yirga, 2010). In line with this, all of the interviewed farmers and traders $(n=62)$ have information to market access about the medicinal plants and their usage, while all of the interviewed traditional healers $(n=8)$ had no access to information (Table 3 ). 
Table 3

Variables in traditional medicinal plant value chain governance

\begin{tabular}{|c|c|c|c|c|c|}
\hline \multirow[t]{3}{*}{ Descriptions of the variables } & & \multicolumn{4}{|c|}{$\begin{array}{l}\text { Response }(\mathrm{n}=70) \\
\text { (50 farmers, } 8 \text { traditional healers and } 12 \\
\text { traders) }\end{array}$} \\
\hline & & \multicolumn{2}{|l|}{ Yes } & \multicolumn{2}{|l|}{ No } \\
\hline & & Frequency & Percent & Frequency & Percent \\
\hline \multirow{3}{*}{$\begin{array}{l}\text { Access to support (financial, Extension, } \\
\text { training, etc.) }\end{array}$} & Farmers & 38 & 54.29 & 12 & 17.14 \\
\hline & Traders & 4 & 5.71 & 8 & 11.43 \\
\hline & $\begin{array}{l}\text { Traditional } \\
\text { healers }\end{array}$ & 1 & 1.43 & 7 & 10.00 \\
\hline \multirow[t]{3}{*}{ Follow negotiable price setting mechanism } & Farmers & 50 & 71.43 & 0 & 0 \\
\hline & Traders & 0 & 0 & 12 & 17.14 \\
\hline & $\begin{array}{l}\text { Traditional } \\
\text { healers }\end{array}$ & 0 & 0 & 8 & 11.43 \\
\hline \multirow[t]{3}{*}{ Trusting value chain actors } & Farmers & 30 & 42.86 & 20 & 28.57 \\
\hline & Traders & 9 & 12.86 & 3 & 4.29 \\
\hline & $\begin{array}{l}\text { Traditional } \\
\text { healers }\end{array}$ & 0 & 0.00 & 8 & 11.43 \\
\hline \multirow[t]{3}{*}{ Information Access } & Farmers & 50 & 71.43 & 0 & 0 \\
\hline & Traders & 12 & 17.14 & 0 & 0 \\
\hline & $\begin{array}{l}\text { Traditional } \\
\text { healers }\end{array}$ & 0 & 0.00 & 8 & 11.43 \\
\hline
\end{tabular}

Source: Survey data result, 2021

\section{Traditional Medicinal plants in Chencha district}

Chencha district is one of the districts in the previous Gamo Gofa zone, today Gamo zone of Southern Ethiopia. The zone is known for its traditional medicinal plants used to treat both human and animal diseases. This is evidenced by the study of Seid and Aydagnehum (2013), mentioning about 89 medicinal plant species used in the area. The local communities obtain medicinal contribution to keep their healthcare system (Abera, 2003; Alemayehu et al., 2016). The major traditional medicinal plants identified in the area during the survey were as follows:

\section{A. Artemisia Anua}

Historically, Artemisia annua was introduced to Ethiopia via a religious institution called Kale Hiwot church in Chencha and is being cultivated on a small scale (WHO, 2006). Today, the plantation and usage of the medicinal plant are largely being expanded in the study area. Artemisia annua is used to treat malaria, haemorrhoids, and cancer, among others (Seid and Aydagnehum, 2013; Watson and Wall, 2017). This is also supported by the study 
described that traditional healers use traditional medicinal products for the treatment of different diseases that range from painkillers to malaria and cancer (Abera, 2003). The leaves of Artemisia annua provide its product after six months of the plantation before it flowers which is considered as the best time where highest artemisinin is found in the leaves (Watson and Wall, 2017) as cited in WHO, 2005. Afterwards, it can be harvested every 3-4 months based on the weather condition which largely affects its growth and flowering. Leaves part of the medicinal plant largely contribute to the economic livelihood improvement of the farmers in the study area. It was mentioned that Artemisia annua is generating income so farmers often provide it to the market just after harvest as they need it to support school fees, cloth purchases, and other expenses (Ven, 2020).

\section{B. Stevia (Stevia rebaudiana Bertoni)}

Stevia is a bushy shrub that is mainly produced in Chencha along with Apple and Artemisia Annua. The local people are using it in the form of tea or juice for people with diabetes (Hossain et al., 2017). This was in line with a study conducted on traditional medicinal plant knowledge and use by local healers that the mentioned juice can be extracted from those plants (Yineger and Yewhalaw, 2007). It is assumed and being practically used to cure diabetes (used instead of sugar), blood pressure, pancreatic cancer, weight control, improves mental consciousness and avoids tiredness, digestion improvements (fastening abdominal and intestine movement) in the study area.

\section{Tulit (Rumex Sanguineus)}

According to Tutin (2001), Tulit (Rumex Sanguineus) is applied in various conditions such as anaemia, vitamin deficiency, gastritis, liver diseases and skin conditions (Matlok et al., 2020). As a medicinal plant, in Chencha district, it is grown by farmers and helpful to the treatment of tonsillitis, skin disease, haemorrhoids and stomach ache (Seid and Aydagnehum, 2013).

\section{Lominat (Lemon verbena)}

Lemon verben (Lominat) is a traditional medicinal plant in Chencha district which is cultivated by Kale Hiwot church in the town. The local communities of Chencha used Lominat to treat bronchitis and common cold, among others. When taken with camomile and Nana mint, it helps to ease the flow of food in the stomach and digestion system.

\section{E. Comfrey and Plantago lanceolata}

Comfrey and Plantago lanceolate are among the medicinal plants grown in the Chencha district. The medicinal plants were assumed to have similar medicinal values. The plants are used locally for fractures, ulcers and fistula, internal and external wound healing, skin warts, diarrhea treatment, and breathing problems (Adom et al., 2017). In addition, the plants are being used to feed poultry, have good blood circulation, and increased soil fertility in the study area. According to Kothmann (2003) and Englert et al. (2005), comfrey was used for the treatment of painful muscle and joint complaints traditionally for centuries (Staiger, 2012).

\section{F. Chamomile (Camomilla Setacciata)}

It is another cultivated and used traditional medicine shrub in Chencha district. Camomile herbal tea is used to ease digestion and help relaxation. The plant is used to treat stomach allergies, abdominal drying. The plant has 
contributed to the health of women and children in the local area. It helps also pregnant mothers and balances menstruation cycle.

\section{G. Milk Thistle (Silybum marianum)}

Silybum marianum (milk thistle) (Fig. 7) is one of the major medicinal plants cultivated and marketed by farmers in Chencha district. It has medicinal value to decontaminate stomach which might be damaged by alcohol or poison, as well as to treat hepatitis and jaundice. Milk thistle is used as pharmaceutical raw material added in food and beverage for health care and applied in anti-aging product for skin care.

\section{H. Marigold (Tagetes erecta)}

Tagetes erecta (marigold) (Fig. 8) is a well-known weed and aesthetic plant with its attractive and shiny orange color flowers as observed in the home compounds and gardens throughout the country. It is also known as a traditional medicinal plant in the Chencha district and many parts of the world, specifically in Europe. The medicinal plant is used for the treatment of skin problems (damaged and allergy-infected skin) (Priyanka et al., 2013). It is also mentioned that it has medicinal value to treat fungal infections including ringworm, athlete's foot, and thrush and wound healing traditional ability (Abera, 2003; Mir et al., 2019). Moreover, farmers in Chencha district mentioned that it is used to balance the menstruation cycle. Marigold also has medicinal value for animals (Kḷvina et al., 2021), and for treating soil as a fertilizer in the study district.

\section{Foeniculum vulgare (fennel)}

Foeniculum vulgare (fennel or local name "Ensilal") (Fig. 9) is a well-known and important medicinal and aromatic plant cultivated throughout the world, including the study areas (Akbar, 2018) and widely used as carminative, digestive, lactogogue and diuretic and in treating respiratory and gastrointestinal disorders (Rather et al., 2016). Farmers in Chencha district also have been using the plant for the treatment of kidney stones, stomach ache and varicose veins.

\section{Medicinal plants in Tulla Sub city and Hawassa city}

During the market survey, in Tulla Sub-city and Hawaasa city farmers were found producing and marketing a few traditional medicinal plants and their products.

In Tulla sub-city, some traditional medicinal plants were found on the farms which the local people used for the treatment of different health problems. Among the major traditional medicinal plants found in Tulla Sub city, Zehneria scabra (locally named "Beso Baqulla") is mentioned. The plant is locally used both for humans and domestic animals to treat evil spirit (Hunde and Asfaw, 2006; Yineger and Yewhalaw, 2007), abdominal ache and diarrhea (Chekole et al., 2015; Woldeab et al., 2018). Moreover, another medicinal plant Echinops kebericho (locally named "Kebericho" or Wogerit in Oromiffa and Amharic languages) were seen in Tula and Basha local markets being sold by local traditional healers (family members) and traders. These medicinal plants were mentioned that they are used to treat skin diseases and to avoid evil spirits taken in the form of perfumed smoke, smearing, and drinking. 
Likewise, Artemisia annua introduced in the area was visited and farmers strived to keep it. However, awareness about harvesting the product from the main plant and absences of monitoring the growth of it was observed as lacking. Whereas a few farmers and traditional healers were found trying to expand Artemisia annua in their agroforestry home gardens that help in reducing long distance travel for traditional medicinal plant product collections (Yirga, 2010). The demand of the species has increased during COVID-19 surge in the study areas and country at large.

In Hawassa city, traditional medicinal plants were found in Hawassa market in the form of value-added and to some extent without value addition. The medicinal plants in Hawassa market comes to market through traders from the surrounding areas with help of secondary/supportive value chain activities carried out by transporters. The major medicinal plants found in Hawassa market are listed in Table 4below.

Table 4

Medicinal plants in Hawassa and their prices

\begin{tabular}{|lll|}
\hline Medicinal plants & Amaharic name & Market price (ETB per 5 gram) \\
\hline Zehneria scabra & Besso baqulla* & $5-10$ \\
\hline Sacred basil & Besso billa & $5-10$ \\
\hline Common rue & Tena adam & 10 \\
\hline Cymbopogon citratus & Tegi sar & 10 \\
\hline Eucalyptus globulus & White eucalyptus & $5-10$ \\
\hline Rosemary & Yesiga metibesha & 10 \\
\hline Black/white cumin & Tikur ena nechi azmud & 10 \\
\hline Coriander & Dimbelal & $5-10$ \\
\hline Lippia adoensis & Koseret & $5-10$ \\
\hline Source: Market survey result, 2021. & \\
\hline *Sidama language, 1 USD $=$ 44 ETB. & \\
\hline
\end{tabular}

\section{Marketing and value addition of traditional medicinal plants in the study areas}

Marketing of traditional medicine plant products has no strong structural function as compared to other business activities in the area and the country in general. Before, the preparation of these and other plants were kept in the house or in the pocket for immediate usage of accidental illness or otherwise they were cultivated or allowed to grow in home gardens for immediate access. An attempt to reconcile the economic exploitation of traditional medicinal plants and biodiversity conservation and to mobilize new sources of societal income (Ingram, 2014) is crucial. The market could link the traditional medicinal plant producers to consumers while understanding constraints faced by the farmers and existing opportunities (Cunningham et al., 2008).

The retailing and handling of indigenous medicines in Chencha, Hawassa, Basha and Tula followed practices prevailing in Ethiopian urban markets. Buyers walk through the narrow streets and foot paths to purchase medicinal 
plants' products from vendors and shops. The number of individual vendors and sellers in small shops varied during days and was highest on busiest on the respective market days of the week. Most of the vendors sold medicinal plants along with spices, incense, and food which is similar to the observations made by Kloos Helmut et.al, 2014 in Merkato Market of Addis Abeba.

Value addition of Artemisia annua in the case of Checha district has profit/marketing margin reward for the actors. Table 5 shows that producers, local assemblers, traders at Arbaminch, and traders at Addis Ababa have a profit share of $28.60 \%, 14.36 \%, 14.31 \%$, and $42.73 \%$, respectively. The higher profit share was that of traders at Addis Ababa followed by the producers of Artemisia annua. The profit share of producers incorporates costs of labour input used for the value addition activities including land preparation, harvesting, drying, milling, and packing. This is because the farmers do not take into account the value of family labour and do not document the amount of labour involved in the aforementioned activities.

Table 5

Market margin for Artemisia annua produced in Chencha district

\begin{tabular}{|c|c|c|c|c|c|c|}
\hline Activity & Unit & Producers & $\begin{array}{l}\text { Local assemblers } \\
\text { /traders/ }\end{array}$ & $\begin{array}{l}\text { Trader } \\
\text { Arbamich }\end{array}$ & $\begin{array}{l}\text { Trader Addis } \\
\text { Ababa }\end{array}$ & Total \\
\hline \multicolumn{7}{|l|}{ Costs } \\
\hline Seedling & Birr/seedling & 20 & - & - & & 20 \\
\hline land preparation & Birr/ day & - & - & - & & \\
\hline Harvesting & Birr & - & - & - & & 0 \\
\hline Drying & Birr & - & - & - & & 0 \\
\hline Sieving/rubbing & Birr & - & - & - & & 0 \\
\hline $\begin{array}{l}\text { Total production } \\
\text { cost }\end{array}$ & Birr & 20 & & & & 20 \\
\hline Transportation & $\begin{array}{l}\text { Birr/1000 } \\
\text { pack }\end{array}$ & 100 & & 80 & 500 & 680 \\
\hline Packing polythene & Birr/pack & 50 & - & - & & 50 \\
\hline Purchasing price & Birr & - & 40000 & 60000 & 60000 & 160000 \\
\hline $\begin{array}{l}\text { Total Marketing } \\
\text { costs }\end{array}$ & Birr & 150 & 40000 & 60080 & 60500 & 160730 \\
\hline $\begin{array}{l}\text { Total cost/1000 } \\
\text { pack }\end{array}$ & Birr & 170 & 40000 & 60080 & 60500 & 160750 \\
\hline Unit Selling price & pack & 40 & 60 & 80 & 120 & 300 \\
\hline $\begin{array}{l}\text { Quantity } \\
\text { sold/purchased }\end{array}$ & Gram & 1000 & 1000 & 1000 & 1000 & 4000 \\
\hline Total revenue & Birr & 40000 & 60000 & 80000 & 120000 & 300000 \\
\hline $\begin{array}{l}\text { Profit/market } \\
\text { margin \% }\end{array}$ & & 28.60 & 14.36 & 14.31 & 42.73 & 100 \\
\hline Note: 1 Pack $=5 \mathrm{gr}$ & & & & & & \\
\hline
\end{tabular}


In addition to Artemisia annua, farmers in Chencha grow traditional medicinal plants as identified by (Seid and Aydagnehum, 2013). Market price and revenue of traditional medicinal plants other than Artimisia anuua in Chencha district were obtained for potentially marketed stevia and milk thistle traditional medicinal plants next to apple and Artimisia annua. However, traditional healers are not willing to sell most of their traditional medicinal plants product at market because of the cultural values and providing relatively organic medicine to the society with low cost (Yineger and Yewhalaw, 2007). Occasionally, even they provide traditional medicinal plant products for free. Thus, certain products have no data on market quantity and standard price.

Table 6

$\otimes$ Traditional plants in Chencha and annual income (ETB) obtained by farmers

\begin{abstract}
Stevia (Stevia rebaudiana Bertoni
Unit selling price/pack $=20$ ETB

Average quantity harvested of stevia per year $=500$ pack

Total revenue $=$ price $*$ quantity $/$ year

$\mathrm{TR}=500 * 20$

TR $=10,000$ birr per year
\end{abstract}

Locally, 1 pack $=5 \mathrm{gram}$. Therefore, farmers in Chencha gains an average income of 10,000 birr per year
Milk thistle - Silybum marianum

Unit selling price $=50 \mathrm{ETB}$

Average quantity harvested of milk thistle per year per single harvest $=100$ packs

Number of harvest per/year $=3$

Total revenue $=$ price *quantity/year

$\mathrm{TR}=300 * 50 \mathrm{birr}$

TR $=15000$ ETB per year

Therefore, farmers in chencha gains an average income of $10,000 \mathrm{ETB}$ per year

Locally, 1 Pack = 5 gram

Tulit- (Rumex sanguineus)

Campfri (Symphytum officinale L)

Market price $=20$ ETB per pack

Market price $=60$ ETB per

Market Quantity = NA (secrecy)

Market Quantity =NA (secrecy)

Source: Market survey data, 2021

\section{Simplified value chain map of traditional medicinal plants in the study area}

The marketing of traditional medicinal plants in the study areas passes through value added market channels. Value chain is one of the expressions that could be used to imply greater sustainability in agro-industrial systems including traditional medicinal plants cultivation (Dar et al., 2017; Pretty, 2008). In this study, qualitative value chain analysis approach was focused to map the value chain of traditional medicinal plants (Hellin and Meijer, 2006; Kaplinsky and Morris, 2000). The roles are carried out by primary and secondary actors involved in value addition and marketing of main and supporting activities, respectively.

\section{Primary value chain actors}

Producers: in the study area, producers primarily play the role of cultivating traditional medicinal plants in the home garden or on-farm. Simultaneously, they carry out harvesting activities of the medicinal plant products both for home consumption as traditional medicine and market to generate income. 
Processors: they are actors who purchase and assemble traditional medicinal plants from producers for the market in Chencha, Tulla, and Hawassa Cities. They sell their products to different traders and consumers in the local and terminal areas after adding value by drying, processing, and packing.

Traders: they are either local or from other areas who are involved in the business of trading traditional medicinal plants purchasing from producers, processors (E.g. Kalehiwot Church in Chencha) and others. Then, they bring the products for sale to different local and non-local consumers.

\section{A. Secondary actors/supporting actors:}

They are actors in the traditional medicinal value addition and marketing activities playing roles of supporting the major activities carried out by the main actors (Porter, 1985). For instance, they provide transportation services (E.g. transport agents), community and technology transfer services via conducting research and providing pieces of training (e.g. Researchers, NGO (Kale Hiwot church and PhytoWood project) (Fig. 11).

The value chain map is intended to summarize the different marketing channels supported with systematic knowledge of the flow of goods and services from conception to the final consumer (Porter, 1985). Eight major marketing channels were identified for the traditional medicinal plants in the study areas (Fig. 11).

\section{Challenges and opportunities of traditional medicinal plants in the study area}

Opportunities and challenges with respect to the on-farm production and marketing of medicinal plants in the study areas were identified. Prevailing challenges at the level of production by farmers included termite destroying medicinal plants; weather condition that pose difficulty in the drying phase of medicinal plants; the absence of green house; and weed management problem. As mentioned previously, farmers do not have the habit of record keeping in terms of labour and management of medicinal plants as well as the indigenous knowledge of medicinal plant uses. This very challenge is confirmed by Yineger and Yewhalaw (2007) with respect to traditional medicinal plants in Jimma Zone, South western Ethiopia. In addressing this challenge, there needs to be awareness creation to prevent Ethiopia's traditional medicinal knowledge from eroding (Yineger and Yewhalaw 2007; Guchale 2021). The current younger generation plays a crucial role to maintain the indigenous traditional medicinal knowledge (Bekele 2007; Giday et al. 2009).

During the market assessment in the study, no form of promotion or advertisement of medicinal plants was observed. Marketing of medicinal plants faced constraints due to limited number of local market outlets, difficult road access for transportation, and lack of support from the local government administration. In terms of value addition activities, given that the rubbing and sieving methods are traditionally done by hand, there is no significant value addition activities involving modern technology. On the one hand, traditional methods preserve the cultural aspects in medicinal plants processing, but on the other hand, better technology could improve the efficiency in processing medicinal plants by farmers.

Nonetheless, the promotion of medicinal plant cultivation and marketing could be leveraged with the opportunities identified in the study. For one, owing to the abundant sunlight, which eases the drying process of harvested medicinal plants, the study areas are thus generally feasible for medicinal plant cultivation and processing. Proclamation no. 661/2009 Article 1 states that no medicine shall be produced and marketed unless it is tested by the executive organ for its safety, efficacy (FDRE, 2010). Thus, this encourages value upgrading of traditional medicinal plant products (FDRE, 2010). Furthermore, since the COVID-19 outbreak, market demand and market price for medicinal plants, particularly Artemisia annua species, have increased in the local markets of the study areas and 
the country at large. Medicinal plant cultivation and processing is a feasible option for farmers to earn additional income, particularly for female farmers. This finding is corroborated by Guchale (2021), who also found the tendency that female farmers plant more medicinal plants than the male counterparts in central Ethiopia. In complementary, male farmers tend to have better knowledge in medicinal plants than female farmers, which could be because sons in the family are preferred in terms of knowledge transfer (Giday et al. 2009).

Existing support by secondary value chain actors was identified to be from non-governmental actors, i.e. Kalehiwot church in Chencha and PhytoWood project in Tulla Sub-City. Thus, the existing support (in the form of training and market opportunities expansion) could be leveraged to address the lack of support in terms of medicinal plant cultivation and marketing from the local government.

\section{Conclusions}

The marketing process of traditional medicinal plants has been largely dealt with in this study in three related approaches, namely the domestication for medicinal values, value chains, and sustainable rural livelihood improvement. It focused on the identification, analysis of economic benefits and value addition opportunities and challenges of traditional medicinal plant products throughout the value chain. Snowball sampling technique was employed to capture primary and secondary data and information from different agents using empirical data collection tools.

Artemisia Anua and Stevia rebaudiana are taking the first and second rank of marketing and value addition in Chencha district; and Zehneria scabra, Echinops kebericho, and Wogerit in Basha town, Tula sub-city, and Hawassa city. The primary actors involved in the study areas were identified to be producers, processors, traders, and consumers with clear and well-defined roles. The major marketing share was gained by the trader actors at a terminal market (Addis Ababa traders). The existence of market demand and support from NGOs (Kalehiwot church) has played a crucial role in providing training and expanding marketing opportunities. Some of the major infrastructural and management challenges faced by the value chain actors of the traditional medicinal plants were identified. Relevant government and non-governmental bodies should support and strengthen the sustainability of cultivation and marketing through linkage of value-adding activities.

Given the current high market demand for medicinal plant products and the local practice to consume medicinal plants to treat diseases and maintain immune system, it shall send market signals to producers as an incentive to cultivate medicinal plants. The present work submits that value addition of medicinal plants in the study areas is relatively understudied. Its secrecy nature remains as a challenge to realize efforts in understanding the value chain governance and market performance of the studied medicinal plants. Nonetheless, we call for an analysis to understand factors driving the adoption of medicinal plants among farmers; the contribution of medicinal plants to farmers' income; biophysical conditions to cultivate medicinal plants in particularly agroforestry systems; and opportunities to commercialize medicinal plants collectively by a farmers' organization. Well-thought policies that incentivize farmers cultivating medicinal plants can contribute maintaining biodiversity in small-scale farms and providing opportunities to diversify farmers' income in the long-run, while securing medicinal supplies in the current context of global health crises.

\section{Declarations}

\section{Availability of data and materials}

Page 15/25 
All data are presented in this article.

\section{Acknowledgements}

The authors would like to thank informants and local administrations in the study area for providing us with valuable and helpful information. This research was supported by the Wood Cluster \& Phyto Wood-Synergies Project at Wondo Genet College of Natural Resource, Hawassa University. Our gratitude also goes to all the project members, community members, and stakeholders in Chencha district, Tulla Sub city and Hawassa city who have collaborated in this research.

\section{Funding}

This study was conducted as a part of the Wood Cluster \& Phyto Wood-Synergies Project, Wondo Genet College of Forestry and Natural Resources, Hawassa University.

\section{Author information}

Affiliations

${ }^{1}$ Hawassa University, Wondo Genet College of Forestry and Natural Resources

Gezehagn Gesese (gezugesemarry@gmail.com), Tsegaye Bekele (bekele57@yahoo.com), and Solomon Erifo (solelf@yahoo.com)

${ }^{2}$ Technische Universität Dresden, Faculty of Environmental Sciences, Institute of International Forestry and Forest Products

Kendisha Soekardjo Hintz (kendisha.hintz@tu-dresden.de)

\section{Contributions}

Gezehagn Gesese, Solomon Erifo and Tsegaye Bekele designed research, collected the data and contributed statistical analysis; Gezehagn Gesese, Solomon Erifo and Tsegaye Bekele and Kendisha Soekardjo conceived of the study and wrote the paper. All authors read and approved the final manuscript.

\section{Corresponding author}

*Correspondence to Gezehagn Gesese.

\section{Ethics approval and consent to participate}

A verbal agreement was obtained from informants prior to implementation. Ethics clearance and official letter has been granted by Wondo Genet College of Natural Resource, Hawassa University.

\section{Consent for publication}

The interviewees were informed about the study's objectives and the eventual publication of the information gathered, and they were assured that the informants' identities would remain undisclosed. 
The authors declare that they have no competing interests.

\section{References}

1. Abera, B., 2003. Medicinal Plants Used in Traditional Medicine in Jimma Zone, Oromia, Southwest Ethiopia 10.

2. Adom, M., Taher, M., Mutalabisin, F., Shahreen, M., Badri, M., Azizi, W., Sengupta, P., Susanti, D., 2017. Chemical constituents and medical benefits of Plantago major. Biomed. Pharmacother. Biomedecine Pharmacother. 96, 348-360. https://doi.org/10.1016/j.biopha.2017.09.152

3. Agize, M., Demissew, S., Asfaw, Z., 2013. Ethnobotany of Medicinal Plants in Loma and Gena Bosa Districts (Woredas) of Dawro Zone, Southern Ethiopia 2(9), 19.

4. Agize, M.; van der Zouwen, L. 2016. Spice and Medicinal Plants Production and Value Chain Analysis from South-West Ethiopia. Journal of Pharmacy and Alternative Medicine Vol. 10: 126-144. https://core.ac.uk/download/pdf/234689545.pdf

5. Akbar, S., 2018. Fennel (Foeniculum vulgare Mill.): A Common Spice with Unique Medicinal Properties 1, 9.

6. Alemayehu, G., Asfaw, Z., Kelbessa, E., 2016. Cordia africana (Boraginaceae) in Ethiopia: A review on its taxonomy, distribution, ethnobotany and conservation status 10.

7. Bekele, E. 2007. Study on actual situation of medicinal plants in Ethiopia.

8. Chekole, G., ASFAW, Z., Kelbessa, E., 2015. Ethnobotanical study of medicinal plants in the environs of Taragedam and Amba remnant forests of Libo Kemkem District, northwest Ethiopia. J. Ethnobiol. Ethnomedicine 11, 4. https://doi.org/10.1186/1746-4269-11-4

9. CSA, 2007. Population and Housing Census of Ethiopia (Annual). Central Statistics Agency, Addis Ababa.

10. Cunningham, A.B., German, L., Paumgarten, F., Chikakula, M., Barr, C., Obidzinski, K., de Koning, R., Purnomo, H., Yatich, T., Svensson, L., Gaafar, A., Puntodewo, A., 2008. Sustainable Trade and Management of Forest Products and Services in the Comesa Region 101.

11. Dar, R.A., Shahnawaz, M., Qazi, P.H., 2017. General overview of medicinal plants: A review 6(6), 3.

12. Endalamaw, T., Lindner, A., Pretzsch, J., 2013. Indicators and Determinants of Small-Scale Bamboo Commercialization in Ethiopia. Forests 4, 710-729. https://doi.org/10.3390/f4030710

13. FDRE, 2010. A Proclamation to Provide for Food, Medicine and Health Care Administration and Control Proclamation No. 661/2009.

14. Giday, M.; Asfaw, Z.; Woldu, Z.; Teklehaymanot, T. 2009. Medicinal plant knowledge of the Bench ethnic group of Ethiopia: an ethnobotanical investigation. Journal of Ethnobiology and Ethnomedicine 5: 34. doi:10.1186/17464269-5-34

15. Guchale, M.G. 2021. Ethnobotanical study of medicinal plants in Tarmaber District, Central Ethiopia: Implication for conservation of biodiversity. Master's Thesis. Technische Universität Dresden, Institute of International Forestry and Forest Products, Tharandt.

16. Hellin, J., Meijer, M., 2006. Guidelines for value chain analysis. Available online at http://www.fao.org/fileadmin/templates/esa/LISFAME/Documents/Ecuador/value_chain_methodology_EN.pdf.

17. Hossain, F., Islam, Mt, School of Education, Bangladesh Open University, Gazipur - 1705, Bangladesh, Islam, Ma, Akhta, S., 2017. Cultivation and uses of stevia (Stevia rebaudiana bertoni): A review. Afr. J. FOOD Agric. Nutr. Dev. 17, 12745-12757. https://doi.org/10.18697/ajfand.80.16595

18. Hunde, D., Asfaw, Z., 2006. USE OF TRADITIONAL MEDICINAL PLANTS BY PEOPLE OF ‘BOOSAT’ SUB DISTRICT, CENTRAL EASTERN ETHIOPIA 15.

Page 17/25 
19. Ingram, V., 2014. Win-wins in forest product value chains?: how governance impacts the sustainability of livelihoods based on non-timber forest products from Cameroon.

20. Kaplinsky, R., Morris, M., 2000. A HANDBOOK FOR VALUE CHAIN RESEARCH 113.

21. Kindie, B., Tamiru, C., 2021. Assessment of traditional medicinal plant Ethnomedicinal value and its sustainable conservation Status used by indigenous people to treat Different Ailments in Babile District, Oromia Region, Ethiopia 6, 6. https://doi.org/10.15406/mojbm.2021.06.00140

22. Kḷaviṇa, A., Keidāne, D., Šukele, R., Bandere, D., Kovalı̌cuka, L., 2021. Traditional Latvian herbal medicinal plants used to treat parasite infections of small ruminants: A review. Vet. World 1548-1558.

https://doi.org/10.14202/vetworld.2021.1548-1558

23. Magalhães, P., Figueira, G., Souza, J., Ventura, A., Ohnishi, M., Silva, D., Lobo, L., Eleres, F., Libonati, R., Willcox, M., Pimentel, E., 2016. Artemisia annua: A New Version of a Traditional Tea under Randomized, Controlled Clinical Trial for the Treatment of Malaria. Adv. Biosci. Biotechnol. 07, 545-563.

https://doi.org/10.4236/abb.2016.712049

24. Matlok, N., Piechowiak, T., Gorzelany, J., Zardzewiały, M., Balawejder, M., 2020. Effect of Ozone Fumigation on Physiological Processes and Bioactive Compounds of Red-Veined Sorrel (Rumex sanguineus ssp. sanguineus). Agronomy 10, 1726. https://doi.org/10.3390/agronomy10111726

25. Mellisse, B.T., van de Ven, G.W.J., Giller, K.E., Descheemaeker, K., 2018. Home garden system dynamics in Southern Ethiopia. Agrofor. Syst. 92, 1579-1595. https://doi.org/10.1007/s10457-017-0106-5

26. Mir, R., Abass, M., Agarwal, R., 2019. Marigold: From Mandap to Medicine and from Ornamentation to Remediation. Am. J. Plant Sci. 10, 309-338. https://doi.org/10.4236/ajps.2019.102024

27. Narita, D., Lemenih, M., Shimoda, Y., Ayana, A.N., 2018. Economic accounting of Ethiopian forests: A natural capital approach. For. Policy Econ. 97, 189-200. https://doi.org/10.1016/j.forpol.2018.10.002

28. Piters, B.D.S., Ghayur, A., Van De Kop, P., 2006. DEVELOPING A SUSTAINABLE MEDICINAL-PLANT CHAIN IN INDIA 12.

29. Porter, M.E., 1985. Competitive advantage: creating and sustaining superior performance. Free Press; Collier Macmillan, New York : London.

30. Pretty, J., 2008. Agricultural sustainability: concepts, principles and evidence. Philos. Trans. R. Soc. B Biol. Sci. 363, 447-465. https://doi.org/10.1098/rstb.2007.2163

31. Priyanka, D., Shalini, T., Verma, N., 2013. A BRIEF STUDY ON MARIGOLD (TAGETES SPECIES): A REVIEW. Int. Res. J. Pharm. 2013.

32. Rather, M.A., Dar, B.A., Sofi, S.N., Bhat, B.A., Qurishi, M.A., 2016. Foeniculum vulgare: A comprehensive review of its traditional use, phytochemistry, pharmacology, and safety. Arab. J. Chem. 9, S1574-S1583. https://doi.org/10.1016/j.arabjc.2012.04.011

33. Scott, R., Ross, I., Hawkins, P., 2016. Fecal Sludge Management: Diagnostics for Service Delivery in Urban Areas 107.

34. Seid, M.A., Aydagnehum, S.G., 2013. Journal of Pharmacognosy and Phytochemistry 2, 10.

35. Staiger, C., 2012. Comfrey: A Clinical Overview. Phytother. Res. PTR 26, 1441-8. https://doi.org/10.1002/ptr.4612

36. Stevia, a sweet medicinal plant that is good for your health, 2021.. Yucatan Times. URL https://www.theyucatantimes.com/2021/03/stevia-a-sweet-medicinal-plant-that-is-good-for-your-health/ (accessed 6.14.21). 
37. Tegen, D.; Dessie, K.; Damtie, D. 2021. Candidate Anti-COVID-19 Medicinal Plants from Ethiopia: A Review of Plants Traditionally Used to Treat Viral Diseases. Evidence-Based Complementary and Alternative Medicine. https://doi.org/10.1155/2021/6622410

38. Tuasha, N., Petros, B., Asfaw, Z. 2018. Medicinal plants used by traditional healers to treat malignancies and other human ailments in Dalle District, Sidama Zone, Ethiopia. Journal of Ethnobiology and Ethnomedicine 14: 15. https://doi.org/10.1186/s13002-018-0213-z

39. Ven, G.W.J., 2020. Living income benchmarking of rural households in low-income countries 23.

40. Watson, J., Wall, R., 2017. Artemisia annua L. GRAS Research 31.

41. WHO, 2006. WHO monograph on good agricultural and collection practices (GACP) for Artemisia annua L. WHO, Geneva.

42. Woldeab, B., Regassa, R., Alemu, T., Megersa, M., 2018. Medicinal Plants Used for Treatment of Diarrhoeal Related Diseases in Ethiopia. Evid. Based Complement. Alternat. Med. 2018. https://doi.org/10.1155/2018/4630371

43. Yineger, H., Yewhalaw, D., 2007. Traditional medicinal plant knowledge and use by local healers in Sekoru District, Jimma Zone, Southwestern Ethiopia. J. Ethnobiol. Ethnomedicine 3, 24. https://doi.org/10.1186/17464269-3-24

44. Yirga, G., 2010. Use of traditional medicinal plants by indigenous people in Mekele town, capital city of Tigray regional state of Ethiopia 4(17), 6.

\section{Figures}

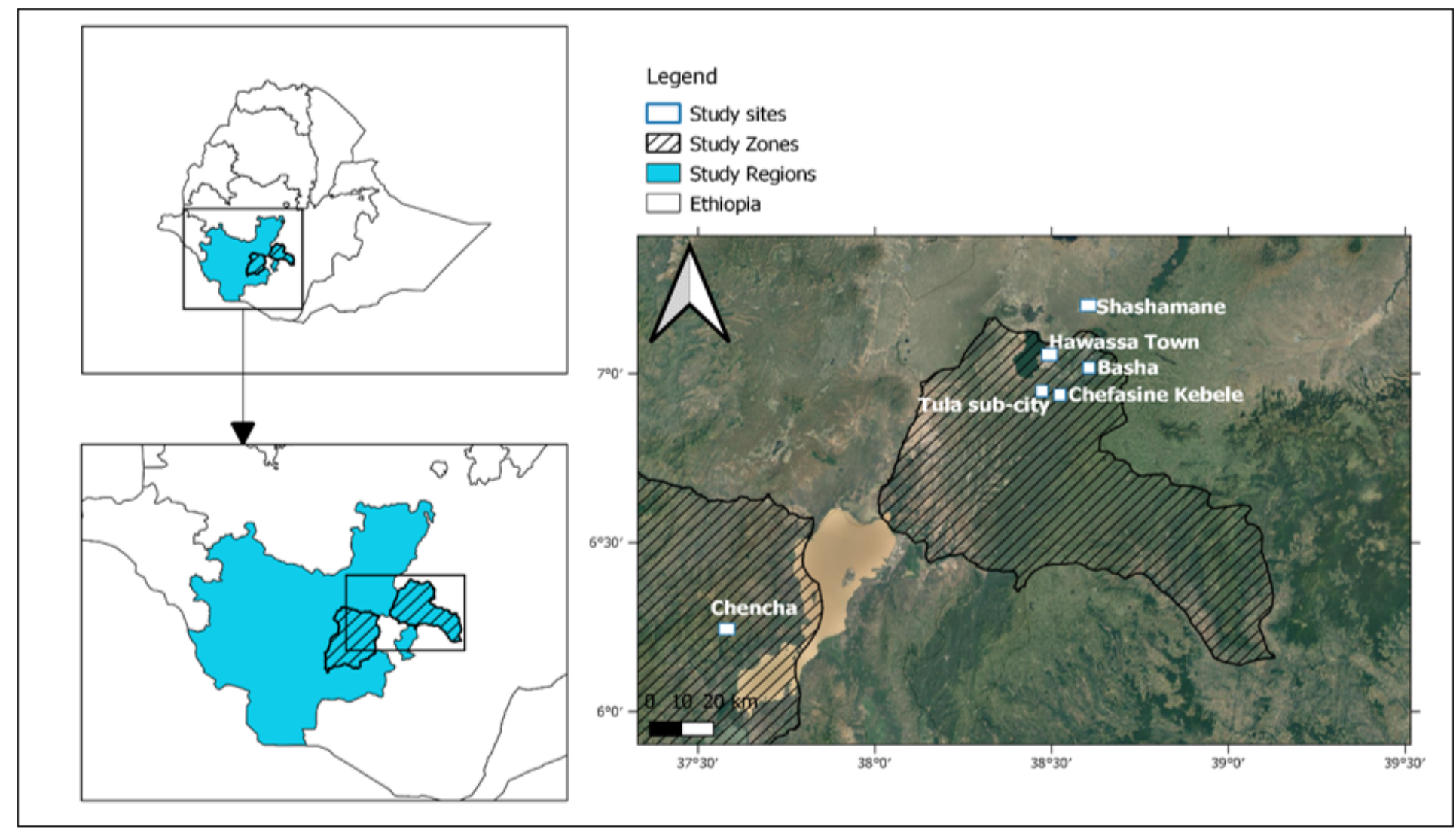

Figure 1 
A.Annua plant

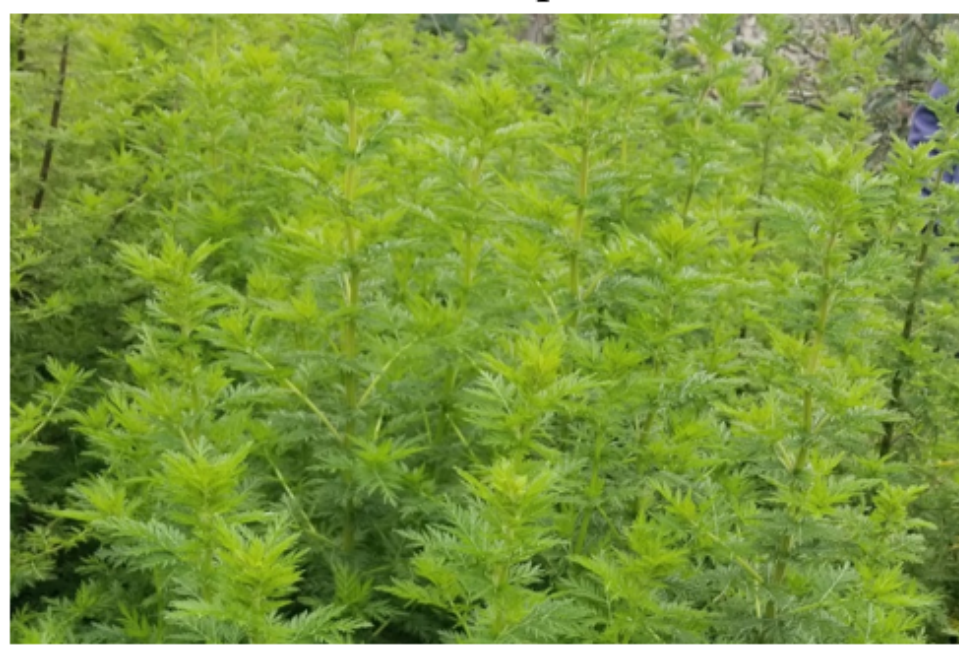

A.annua open air drying of leaves

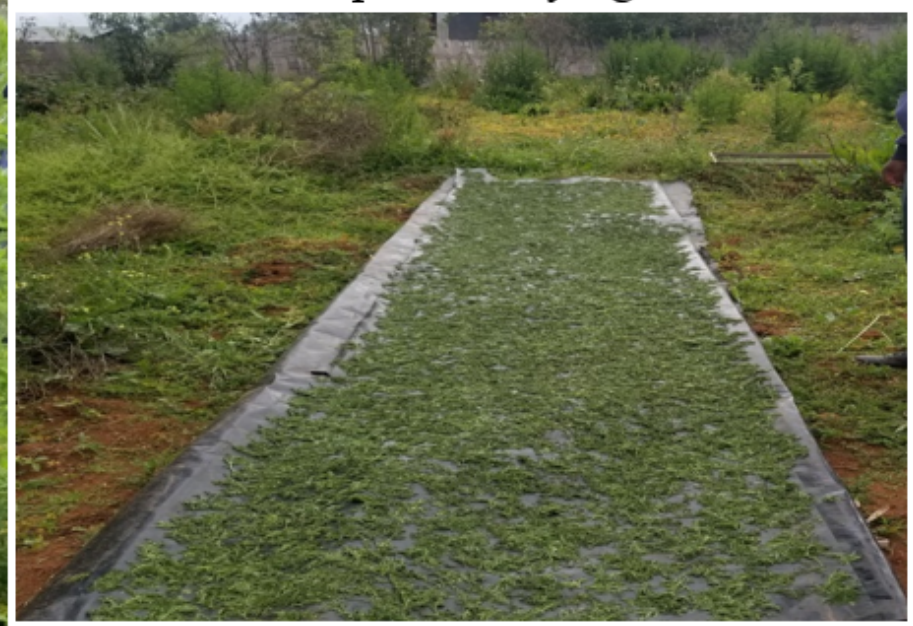

Figure 2

Artemisia Annua in Chencha Source: Authors, 2021

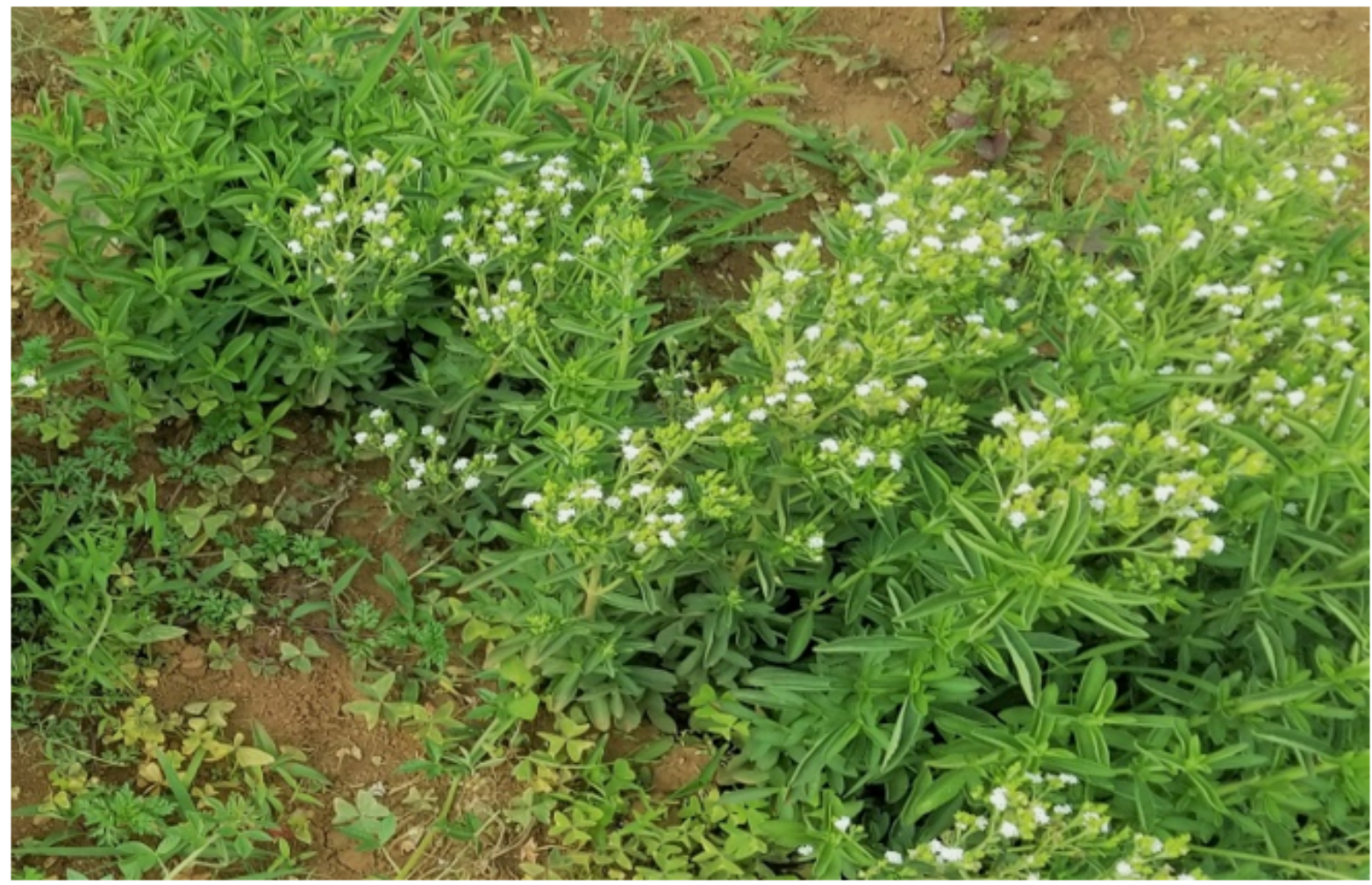

\section{Figure 3}

Stevia medicinal plant in Chencha district Source: Authors, 2021 


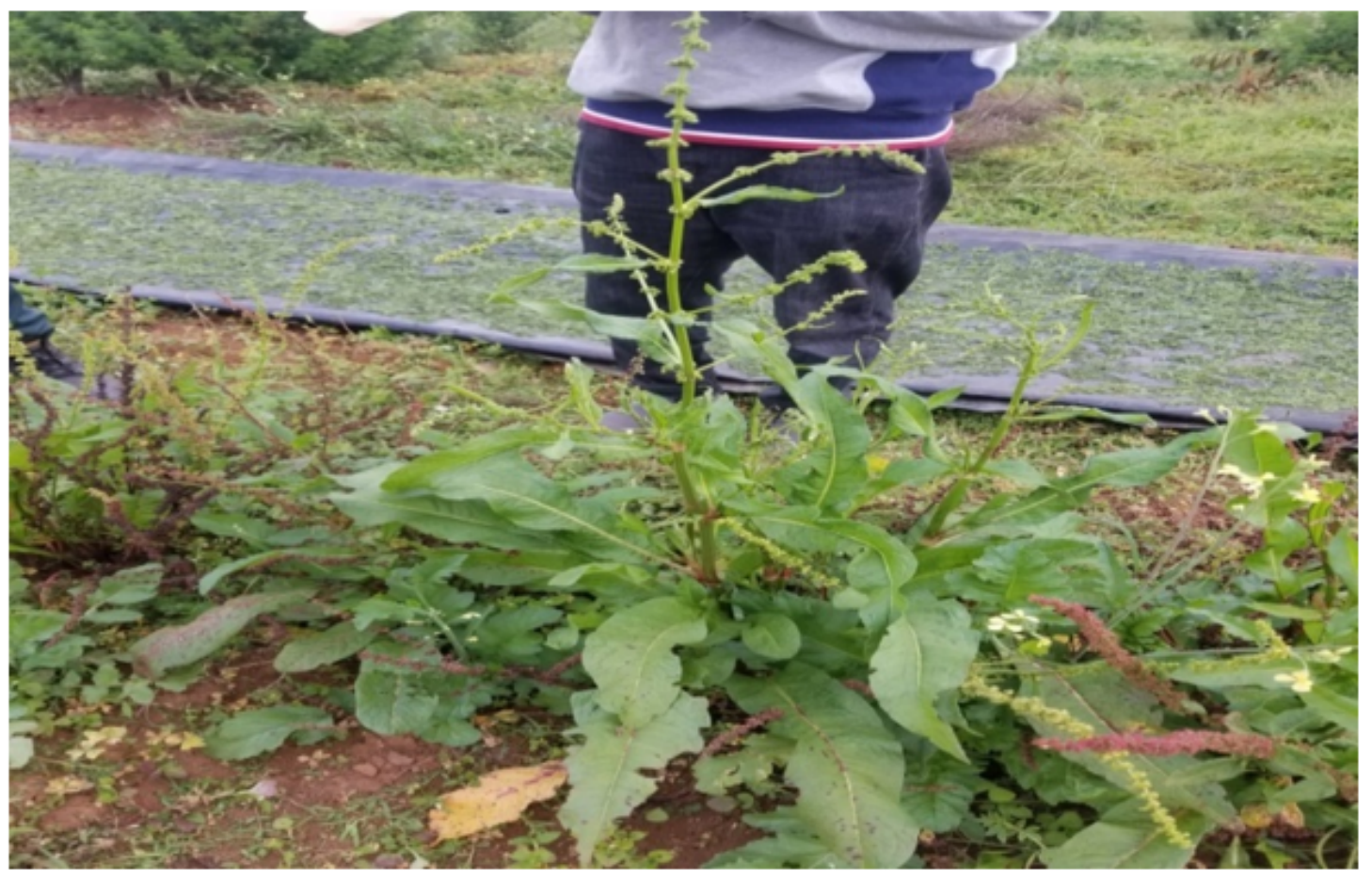

\section{Figure 4}

Tulit medicinal plant in Chencha Source: Authors, 2021
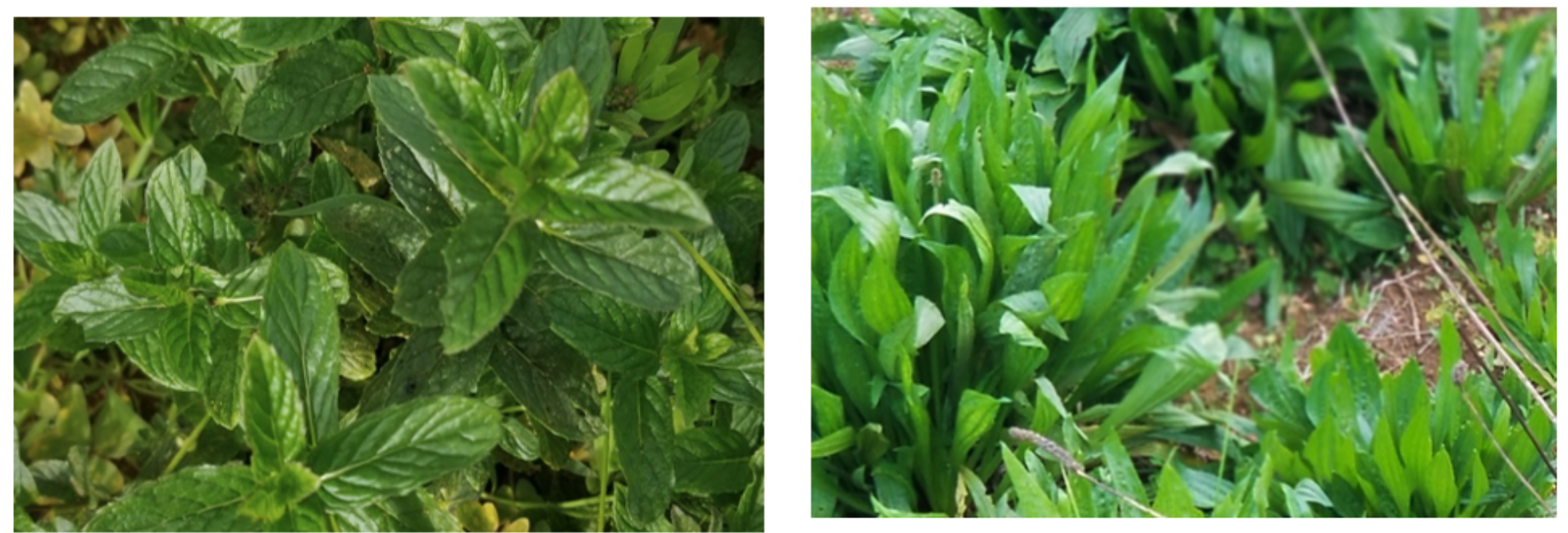

\section{Figure 5}

Comfrey (left) and Plantago lanceolata (right) medicinal plants Source: Authors, 2021 


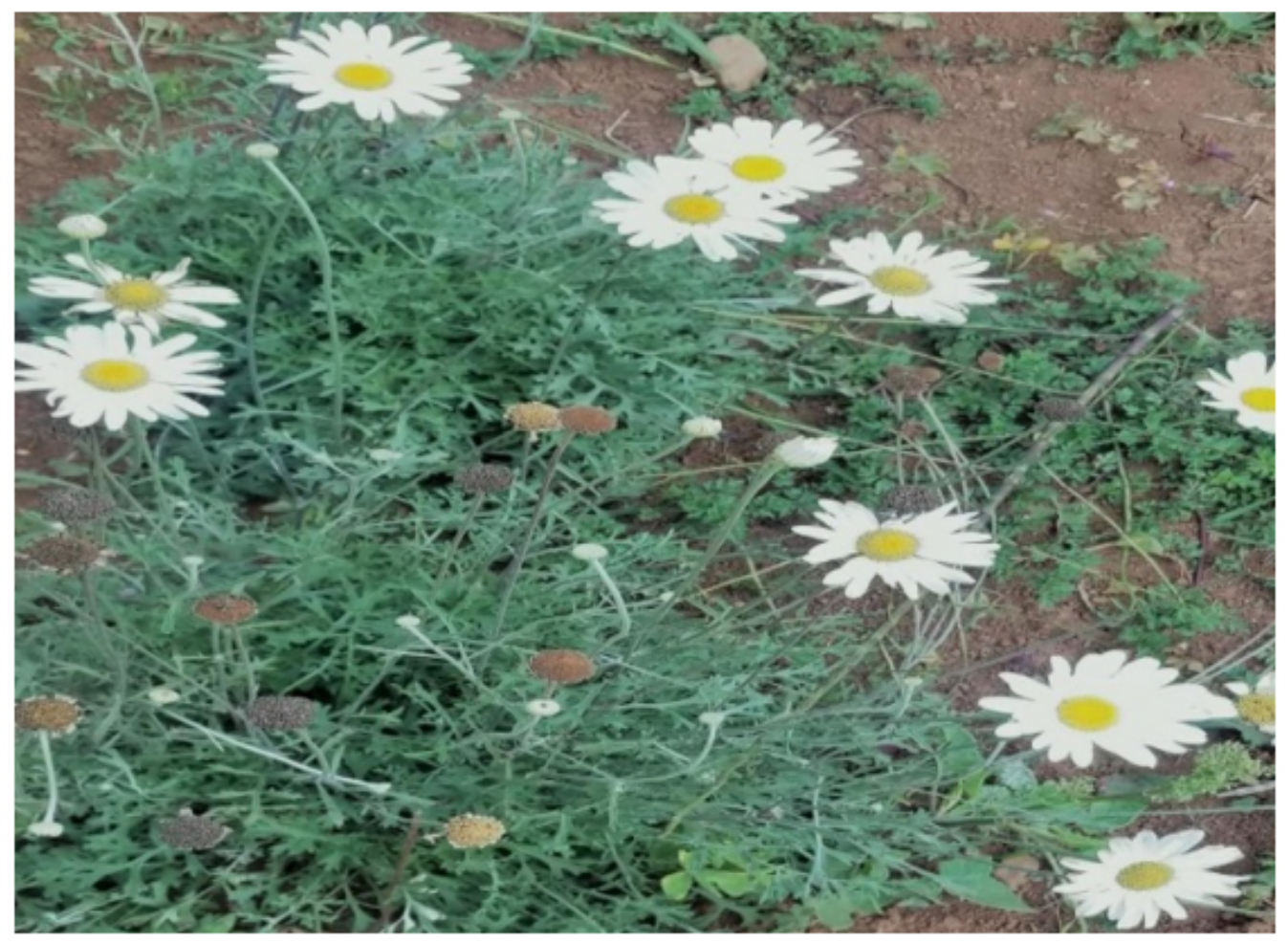

\section{Figure 6}

Chamomile traditional medicinal plant in Chencha district Source: Authors, 2021

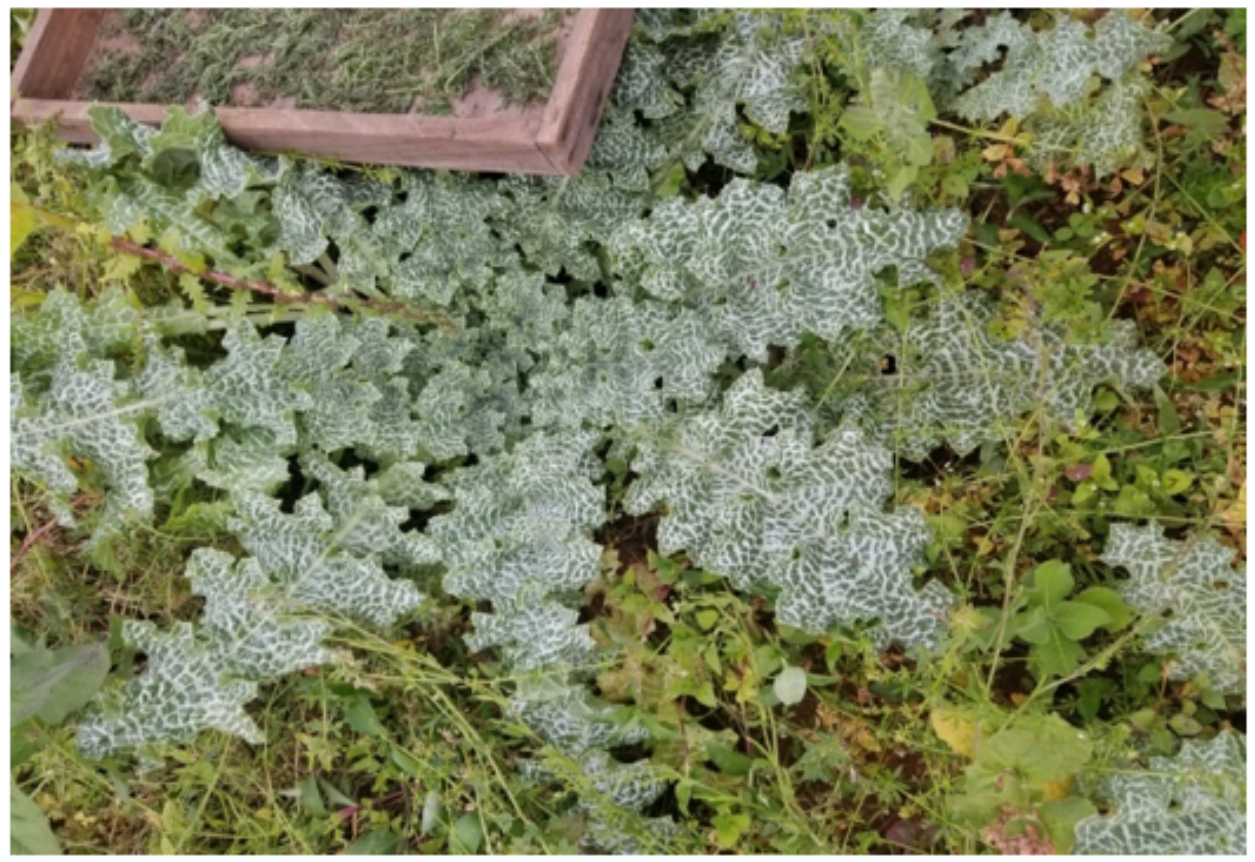

\section{Figure 7}

Milk thistle medicinal plant in Chencha Source: Authors, 2021 


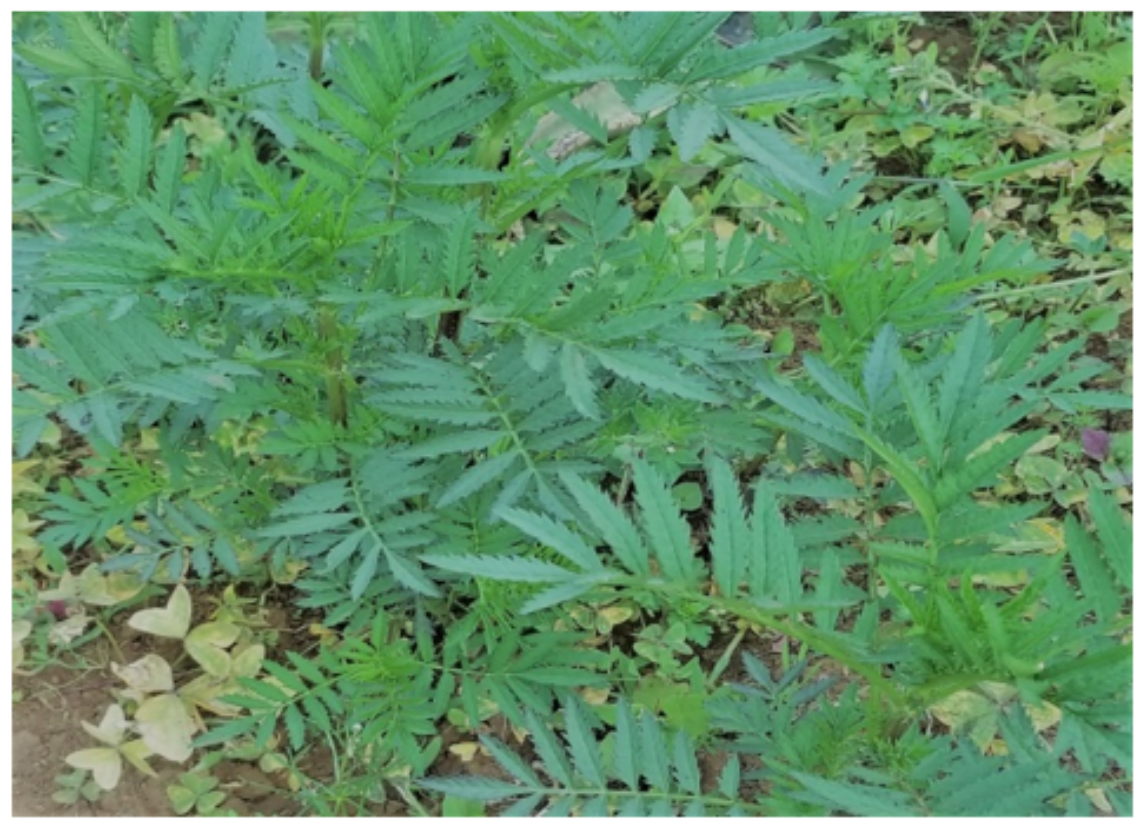

\section{Figure 8}

Marigold traditional medicinal plant in Chencha district Source: Authors, 2021

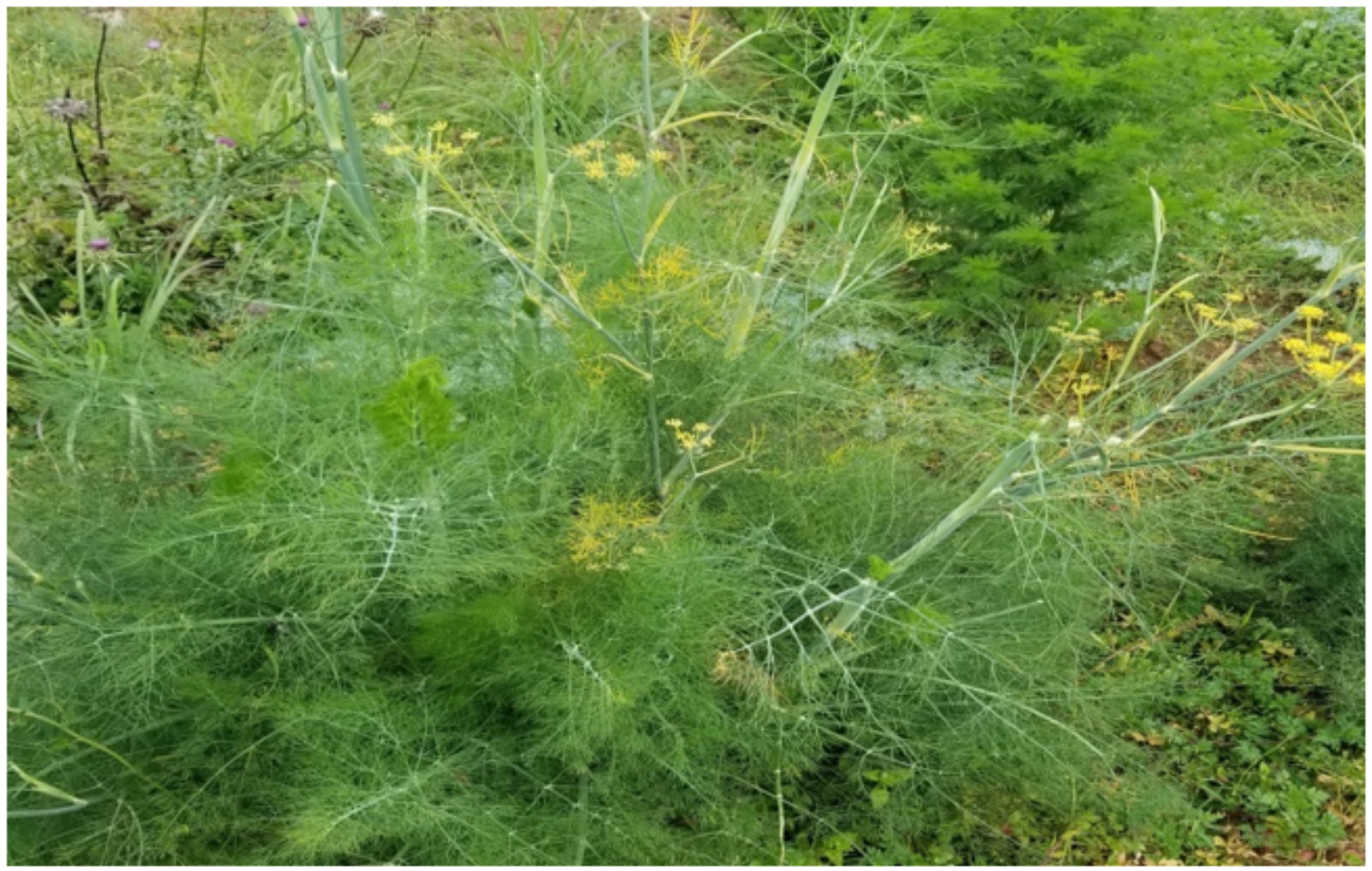

\section{Figure 9}

Foeniculum vulgare (Ensilal) in Chencha Source: Photo by researchers, 2021 

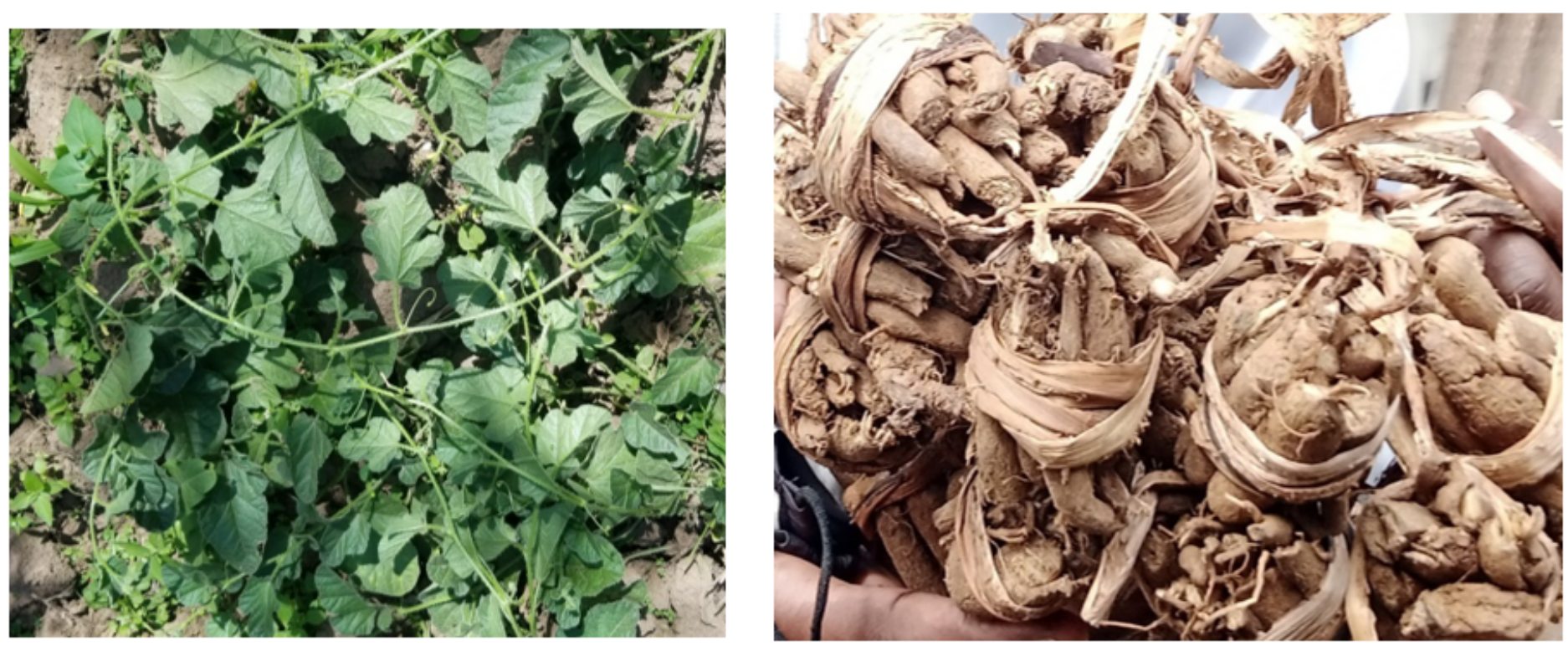

\section{Figure 10}

Zehneria scabra (Beso baqula in Sidama language) in Chefasine (left) and Kebericho in local market of Tulla sub city (right) 


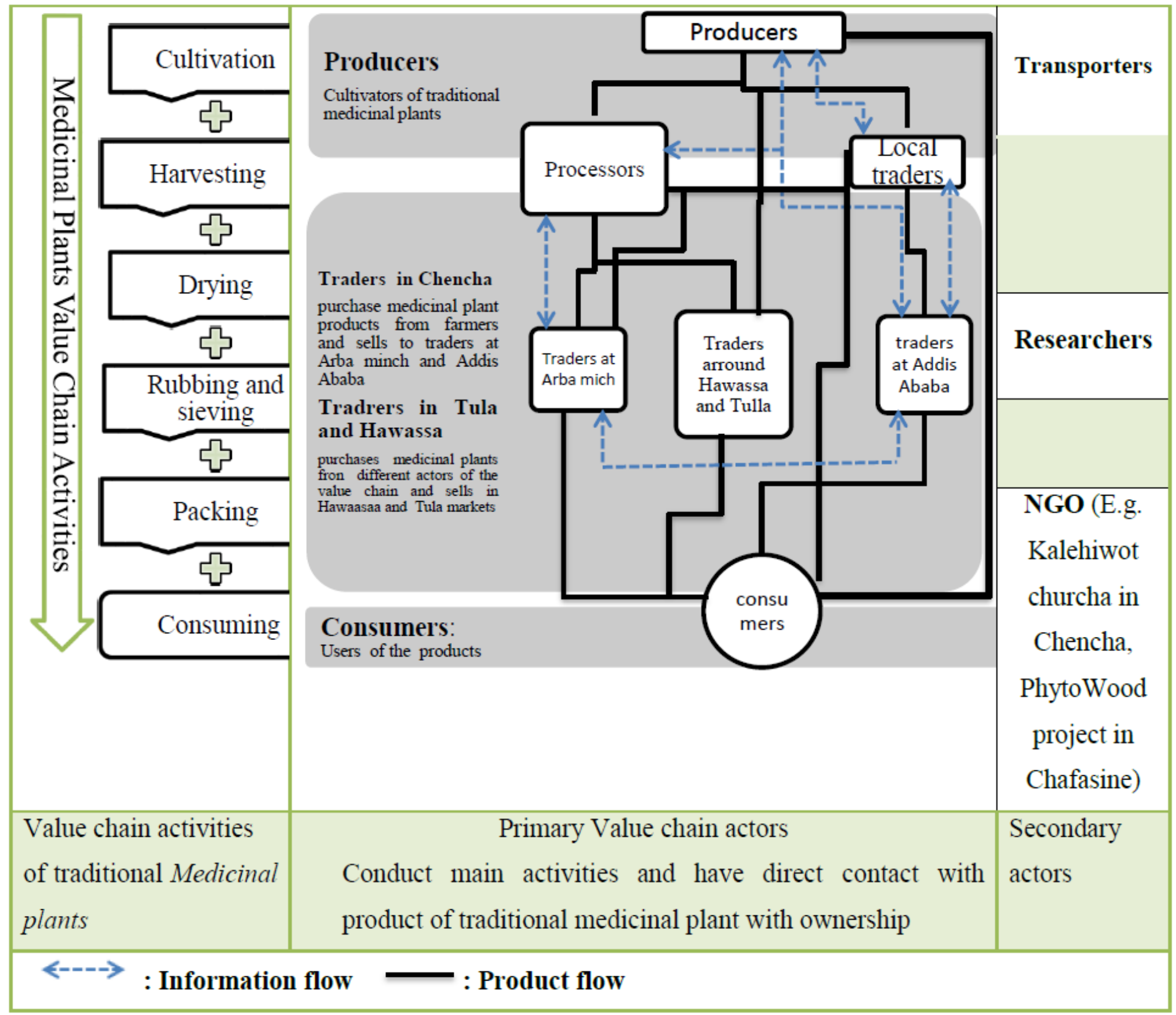

Figure 11

Simple value chain map of traditional medicinal plants Source: Survey data results and own sketch, 2021

\section{Supplementary Files}

This is a list of supplementary files associated with this preprint. Click to download.

- Supplementarymaterial1.pdf 